\title{
Differential Regulation of Chemokine Expression by Th1 and Th2 Cytokines and Mechanisms of Eotaxin/CCL-11 Expression in Human Airway Smooth Muscle Cells
}

\author{
Miho Odaka ${ }^{a}$ Satoshi Matsukura ${ }^{a}$ Hideki Kuga $^{a}$ Fumio Kokubu ${ }^{b}$ Tsuyoshi Kasama ${ }^{a}$ \\ Masatsugu Kurokawa ${ }^{a}$ Mio Kawaguchi ${ }^{a}$ Koushi leki $^{\mathrm{a}}$ Shintaro Suzuki ${ }^{\mathrm{a}}$ Shin Watanabe ${ }^{\mathrm{a}}$ \\ Tetsuya Homma ${ }^{a}$ Hiroko Takeuchi ${ }^{\mathrm{a}}$ Kyoko Nohtomi ${ }^{\mathrm{a}}$ Robert P. Schleimer ${ }^{\mathrm{c}}$ Mitsuru Adachi ${ }^{\mathrm{a}}$ \\ ${ }^{a}$ First Department of Internal Medicine, Showa University School of Medicine, Tokyo, and \\ ${ }^{b}$ Department of Respiratory Internal Medicine, Showa University Fujigaoka Hospital, Kanagawa, Japan; \\ 'Northwestern University Feinberg School of Medicine, Chicago, III., USA
}

\section{Key Words}

Interleukin-4 - Signal transducer activator of transcription 6 •

Eotaxin $\cdot$ Smooth muscle cells

\begin{abstract}
Background: Airway smooth muscle (ASM) cells may contribute to the pathogenesis of asthma including airway inflammation and remodeling. We focused our study on the regulation of chemokine expression by cytokines and analyzed the mechanisms of eotaxin/CCL-11 expression in ASM cells. Methods: Human ASM cells were cultured in vitro and treated with IL-4, interferon- $\gamma$ (IFN $\gamma$ ), and tumor necrosis factor- $\alpha$ (TNF $\alpha)$. Secretion of chemokines into the culture medium was analyzed by ELISA. Expression of eotaxin mRNA was analyzed by reverse transcription-polymerase chain reaction (RT-PCR). Binding of transcription factor signal transducer activator of transcription (STAT) 6 to the eotaxin promoter-derived DNA was analyzed by pull-down Western blot. To assess transcriptional regulation of eotaxin, cells were transfected with eotaxin promoter-luciferase reporter plasmids, and activity was determined by dual luciferase assay. Results: The Th2 cytokine IL-4 preferentially stimulated the expression of the CC chemokine receptor (CCR) 3-ligand
\end{abstract}

chemokines eotaxin, eotaxin-3, and MCP-4. The Th1 cytokine IFN $\gamma$ stimulated the expression of chemokines IP-10 and RANTES. IL-4 stimulated nuclear translocation of signal transducer activator of transcription 6 (STAT6) and its binding to the eotaxin promoter region. IL-4 activated the eotaxin promoter and its activity was inhibited by mutation of the binding site for STAT6 in the promoter. Conclusions: The Th2 cytokine IL-4 preferentially stimulated the expression of CCR3 ligand chemokines including eotaxin in ASM cells. The transcription factor STAT6 may play a pivotal role in the activation of eotaxin transcription in response to IL-4.

Copyright $\odot 2007$ S. Karger AG, Basel

\section{Introduction}

Hyperplasia and hypertrophy of airway smooth muscle (ASM) cells are important aspects of airway remodeling, and these pathologic features may be involved in airway narrowing, airway hyperresponsiveness, and disease severity of asthma $[1,2]$. ASM cells are involved in constriction of the airways in patients with asthma. Recent data have also implicated that ASM cells produce chemokines, including eotaxin, and contribute to the infiltra-

\section{KARGER}

Fax +41613061234

E-Mail karger@karger.ch

www.karger.com
(C) 2007 S. Karger AG, Basel

$1018-2438 / 07 / 1435-0084 \$ 23.50 / 0$

Accessible online at:

www.karger.com/iaa
Correspondence to: Dr. Miho Odaka

First Department of Internal Medicine

Showa University School of Medicine, 1-5-8 Hatanodai, Shinagawa-ku

Tokyo 142-8666 (Japan)

Tel. +81 33784 8532, Fax +81 33784 8742, E-Mail miho-odk@gk9.so-net.ne.jp 
tion of inflammatory cells into airway and pathogenesis of airway remodeling.

Brightling et al. [3] reported that mast cells infiltrate the smooth muscle layer in patients with asthma. Mast cells are known to secrete chemical mediators and cause constriction of smooth muscle. The proliferation of ASM cells is thought to be mediated by mast-cell-derived tryptase, chemical mediators, such as histamine and leukotrienes, and cytokines, such as transforming growth factor$\beta$ (TGF $\beta$ ) and tumor necrosis factor- $\alpha$ (TNF $\alpha)$. Interaction of ASM cells and mast cells may be involved in the pathophysiology of asthma [4]. Recent reports showed that mast cells express chemokine receptors including CC chemokine receptor (CCR) 1, CCR3, CCR5 and CXC chemokine receptor (CXCR)3 [5]. RANTES/CCL5 is a ligand for CCR1, CCR3 and CCR5. Eotaxin/CCL11 is a ligand for CCR3. IP-10/CXCL10 is a ligand for CXCR3. These chemokines are known to cause chemotaxis of mast cells in vitro study and may be important for the migration of mast cells into smooth muscle layer in asthmatics [6-8].

In this study, we investigated the regulation of expression of chemokines by cytokines in ASM cells in vitro and next focused our study on the mechanism of regulation of expression of eotaxin.

\section{Materials and Methods}

\section{Reagents}

Recombinant cytokines IL-4, IFN $\gamma$, and TNF $\alpha$ were purchased from R\&D Systems, Tokyo, Japan.

\section{Cell Culture}

Human airway smooth muscle cells were purchased from Cambrex (Baltimore, Md., USA) and cultured in SmBM medium with SmGM-2 SingleQuots (Cambrex) containing insulin, FGF, gentamicin, $5 \% \mathrm{FBS}$, and $\mathrm{EGF}$ at $37^{\circ} \mathrm{C}$ with $5 \% \mathrm{CO}_{2}$ in humidified air. Confluent cells at passage $2-5$ were stimulated with cytokines as described below.

\section{Assay of Chemokine Secretion}

Concentrations of eotaxin, eotaxin-2/CCL24, eotaxin-3/ CCL26, MCP-4/CCL13, RANTES/CCL5, and IP-10/CXCL10 in the culture medium were determined with a commercially available enzyme-linked immunosorbent assay (ELISA) kit (R\&D Systems) as described previously [9].

\section{Assay of Eotaxin mRNA Expression}

Purification of RNA and synthesis of cDNA were performed as described previously [10]. Predesigned TaqMan probe sets for eotaxin was purchased from Applied Biosystems (Tokyo, Japan) and real-time PCR was performed as described previously [9]. Data are shown as fold induction of nonstimulated control cells.
Extraction of Nuclei and Pull-Down-Western Blot

Nuclear translocation of signal transducer activator of transcription (STAT) 6 and the binding to the DNA probe which contains the sequence derived from eotaxin promoter region was analyzed by pull-down-Western blot method as described previously [11]. The sequence of the oligonucleotide probe used is 5'-GGCTTCCCTGGAATCTCCCACA-3' (site -77 to -56) which contains the binding site for STAT6.

\section{Assay of Eotaxin Promoter Activity}

Methods for the construction of eotaxin promoter-reporter plasmids have been described [11]. A 1,363-bp fragment of the promoter region of the eotaxin gene (site -1363 to -1 ) which contains binding sites for nuclear factor-kappa B (NF-kB) and STAT6 was ligated to the luciferase reporter $\mathrm{pGL} 3$-Basic vector (Promega Corp., Madison, Wisc., USA). The construct is referred to as pEotx.1363 (see fig. 4). Construct pEotx. M1 was synthesized by mutating the STAT6 binding site in pEotx.1363. ASM cells at passage 2 were seeded onto 6 -well plates and allowed to grow to $50 \%$ confluence. Cells were transfected with $1 \mu \mathrm{g}$ of each reporter plasmid and $10 \mathrm{ng}$ of the control renilla-luciferase vector pRL-TK (Promega) with $5 \mu$ l lipofectamine 2000 (Promega) and grown in medium without gentamicin for $24 \mathrm{~h}$. The medium was changed to medium containing gentamicin. After $24 \mathrm{~h}$, cells were incubated with the indicated cytokines for $20 \mathrm{~h}$. Cells were solubilized by incubation in $500 \mu \mathrm{l}$ lysis buffer for $20 \mathrm{~min}$ and luciferase activity was measured with the Dual-Luciferase Assay System (Promega) and a luminometer (Gene-Light 55; Microtech Nichion, Chiba, Japan). Firefly-luciferase activity of the reporter plasmid was normalized to renilla-luciferase activity and expressed as fold induction of control.

Statistical Analysis

Data were expressed as mean \pm SEM. Statistical differences were determined by analysis of variance with Fisher protected least significant difference. Data were analyzed with Stat View IV (Abacus Concepts, Berkeley, Calif., USA).

\section{Results}

\section{Differential Regulation of Chemokine Expression by}

Cytokines in ASM Cells

IL-4 stimulated the secretion of eotaxin (fig. 1a), eotaxin-3 (fig. 1b), and MCP-4 (fig. 1c) protein into the culture medium at $24 \mathrm{~h}$ after stimulation, but it did not stimulate secretion of RANTES or IP-10. TNF $\alpha$ alone did not stimulate the secretion of eotaxin, eotaxin-3, and MCP-4, but it enhanced the effect of IL-4. IFN $\gamma$ did not stimulate the secretion of eotaxin, eotaxin-3, and MCP-4. However, IFN $\gamma$ alone or the combination of TNF $\alpha$ and IFN $\gamma$ significantly stimulated the secretion of RANTES (fig. 1d) and IP-10 (fig. 1e). Eotaxin-2 was not detected under any condition (data not shown). 


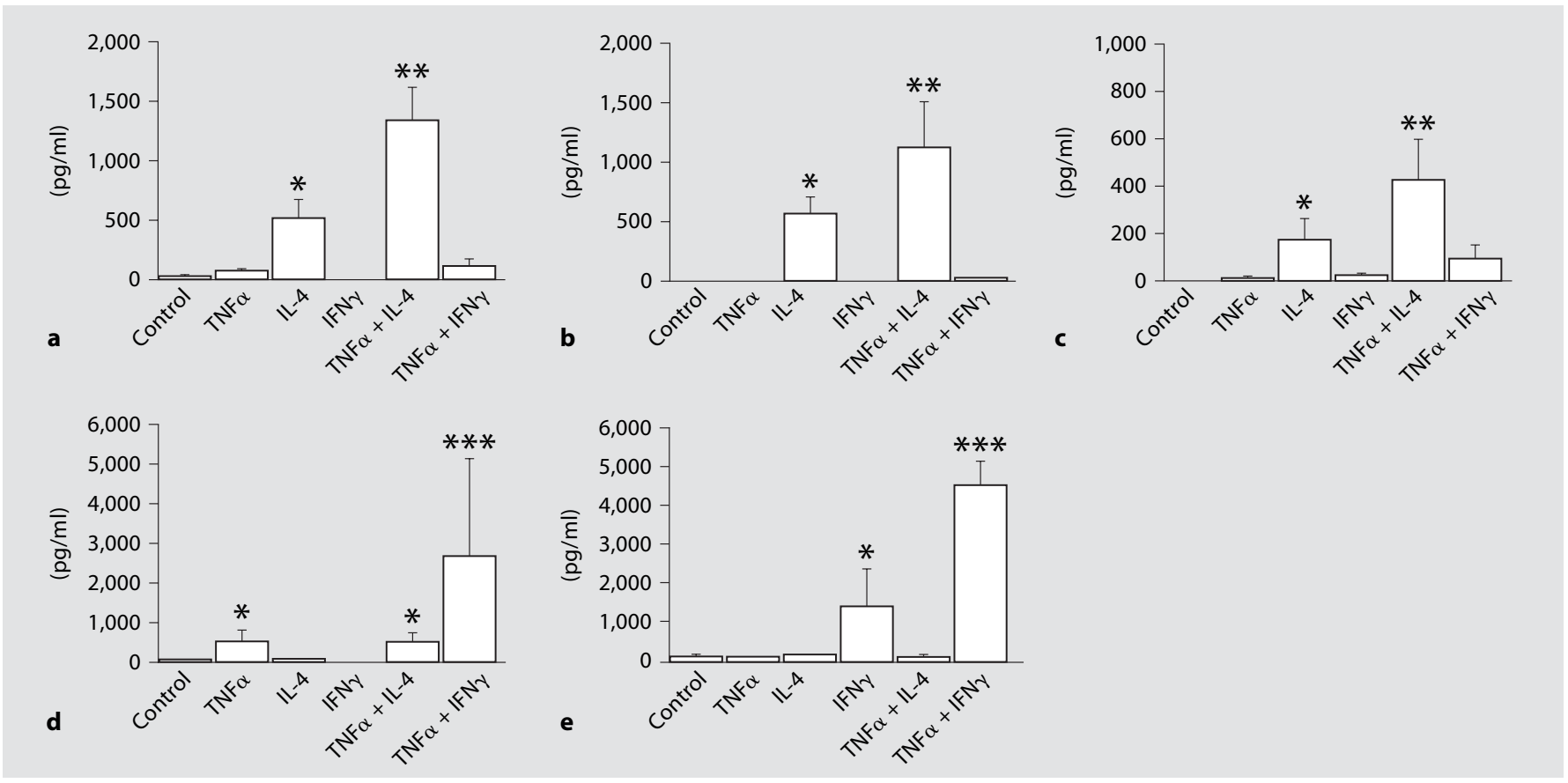

Fig. 1. Secretion of chemokine proteins into the medium of airway smooth muscle (ASM) cells. a Eotaxin/CCL11. b Eotaxin-3/ CCL26. c MCP-4/CCL13. d RANTES/CCL5. e IP-10/CXCL10. Medium was collected from cells stimulated with $10 \mathrm{ng} / \mathrm{ml} \mathrm{IL-4,}$ IFN $\gamma$, and/or TNF $\alpha$ for $24 \mathrm{~h}$ and subjected to ELISA. The data are presented as the mean \pm SEM of five independent experiments. ${ }^{*} \mathrm{p}<0.05$ compared to nonstimulated control cells. ${ }^{* *} \mathrm{p}<0.05$ compared to stimulation with IL-4. ${ }^{* * *} \mathrm{p}<0.05$ compared to stimulation with TNF $\alpha$ or IFN $\gamma$.
Fig. 2. Regulation of eotaxin mRNA expression in airway smooth muscle (ASM) cells. RNA was extracted from cells which had been stimulated with $10 \mathrm{ng} / \mathrm{ml} \mathrm{IL-4,} \mathrm{and/or} \mathrm{TNF} \alpha$ for $24 \mathrm{~h}$ and subjected to real-time PCR. Levels of mRNA were calculated as fold induction compared with nonstimulated control. The data are presented as the mean \pm SEM of three independent experiments. ${ }^{*} \mathrm{p}<0.05$ as compared with nonstimulated cells. ${ }^{* *} \mathrm{p}<$ 0.05 as compared with the cells stimulated with IL-4.

Fig. 3. Nuclear translocation of STAT6 and its binding to the proximal region of the eotaxin promoter. Nuclear protein was extracted from airway smooth muscle (ASM) cells treated with or without $10 \mathrm{ng} / \mathrm{ml} \mathrm{IL-4,} \mathrm{and/or} \mathrm{TNF} \alpha$ for $30 \mathrm{~min}$. The extract was precipitated with an oligonucleotide probe which contains a putative binding site for STAT6 derived from the eotaxin promoter. The extract was analyzed by Western blot using an STAT6 Ab. Results are representative of three independent experiments.
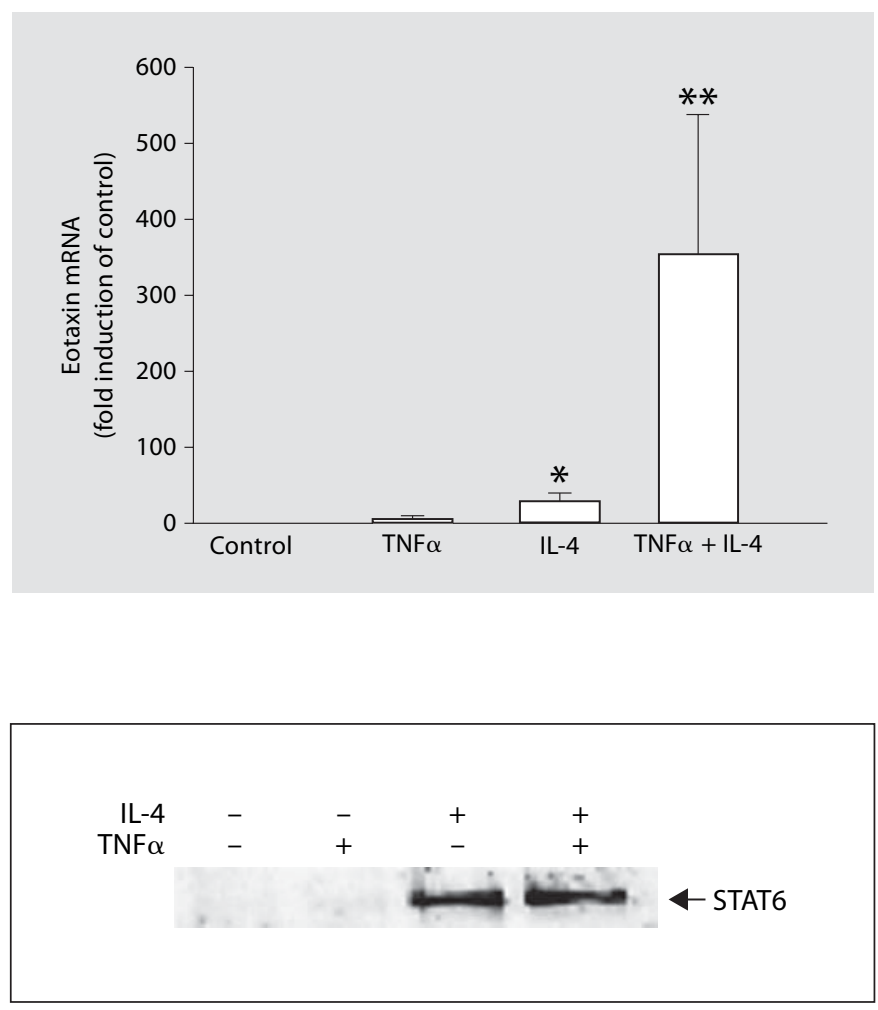
Fig. 4. Luciferase reporter assays of the eotaxin promoter in airway smooth muscle (ASM) cells. Cells were transfected with the eotaxin promoter-luciferase reporter plasmids illustrated in the figure (pEotx.1363 and M1) and control vector pRLTK. Forty-eight hours later, cells were stimulated for $20 \mathrm{~h}$ with or without $10 \mathrm{ng} /$ $\mathrm{ml}$ IL- 4 and TNF $\alpha$. The relative luciferase activity was calculated as fold induction compared with the control value. The data are presented as the mean \pm SEM of a total of five independent experiments. ${ }^{*} \mathrm{p}<$ 0.05 as compared with non-stimulated control cells. a pEotx.1363. b pEotx. M1.

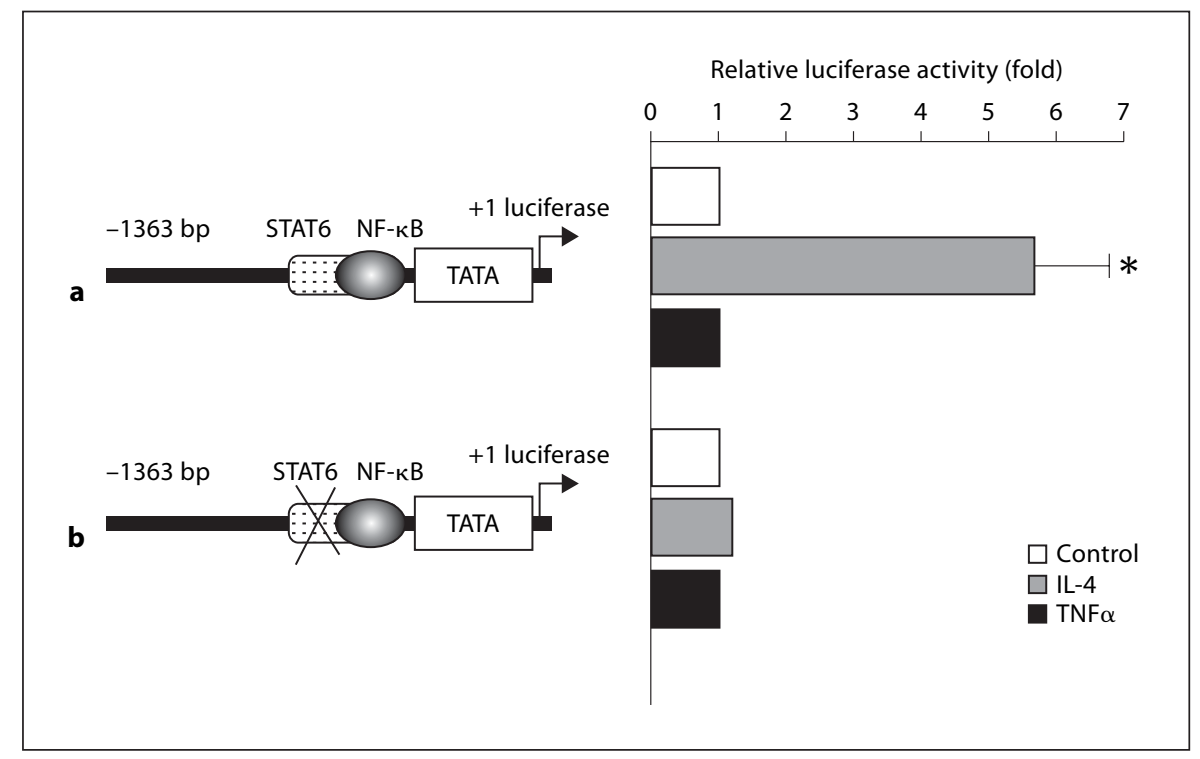

\section{Upregulation of the Expression of Eotaxin mRNA by}

IL-4

We next focused our study on the mechanisms of regulation of eotaxin expression by IL-4 in ASM cells. IL-4 stimulated the expression of eotaxin mRNA at $24 \mathrm{~h}$ after stimulation (fig. 2). TNF $\alpha$ alone did not stimulate the expression, but significantly enhanced the effect of IL-4.

\section{Binding of STAT6 to the Eotaxin Promoter Region}

Nuclear protein extracted at 30 min after stimulation with IL-4 reacted with a DNA probe which contains the sequence of eotaxin promoter region. This complex was confirmed to contain STAT6 by Western blot (fig. 3). TNF $\alpha$ did not interfere with the formation of the STAT6 complex.

\section{Assay of Eotaxin Promoter Activity}

To analyze the function of STAT6 in ASM cells, we examined the regulation of eotaxin transcription by IL- 4 . IL-4 activated the eotaxin promoter reporter pEotx.1363 (fig. 4a). Activation of the promoter by IL- 4 was lost in pEotx. M1 lacking a STAT6 site (fig. 4b). TNF $\alpha$ did not activate the promoter.

\section{Discussion}

In this study, we showed that cytokines differentially regulate the expression of chemokines in ASM cells. Th2 type cytokine IL-4 preferentially stimulated the expres- sion of CCR3-specific ligands such as eotaxin, eotaxin-3, and MCP-4. Th1 type cytokine IFN $\gamma$ tended to stimulate the expression of IP-10, a ligand of CXC chemokine receptor (CXCR) 3, and RANTES, a ligand of CCR1, CCR3 and CCR5. In our knowledge, we here report MCP-4 expression in ASM cells for the first time. Other chemokine expressions in ASM have been reported, but reports comparing the efficacy of Th1 and Th2 cytokines in induction of chemokines seem few [12-19]. However, our data may facilitate an understanding of the tendency of differential regulation of chemokine expression by Th1 and Th2 cytokines. Th2 cell express CCR3, CCR4 and CCR8. Th1 cells express CXCR3 and CCR5. Th2 cells produce IL- 4 and are believed to contribute to the pathogenesis of allergic disease including asthma. Induction by Th2 cytokines of the expression of eotaxin, eotaxin-3, and MCP4 may favor the recruitment of Th2 cells, eosinophils, basophils, and mast cells into the airway.

We previously reported that TNF $\alpha$ stimulates eotaxin expression through activation of NF-kB in airway epithelial cells [11]. However, TNF $\alpha$ alone did not stimulate eotaxin expression in ASM cells. The potency of IL-4 as an inducer of eotaxin expression in ASM cells seemed much higher than in airway epithelial cells. We showed that STAT6 is important for activation of eotaxin transcription by IL-4 in ASM cells. Other investigators reported that IL-4 and IL-13 induce phosphorylation of STAT6 in ASM cells [14]. Peng et al. [16] reported that antisense oligodeoxynucleotides of STAT6 inhibited expression of eotaxin induced by IL- 4 and IL-13. Our data support these 
previous data and also clarified that STAT6 actually binds to the eotaxin promoter region and this binding site is necessary to activate the transcription of eotaxin.

Further studies will be needed to determine if the expression of eotaxin- 3 and MCP- 4 are also regulated by STAT6 in response to Th2 cytokines in ASM cells. Finally, our studies support the concept that STAT6 may be an important therapeutic target for the treatment of asthma.

\section{Acknowledgments}

The authors would like to thank Dr. T. Hirano for his excellent assistance. This work was supported by grants from the Environmental Restoration and Conservation Agency and GlaxoSmithKline.

\section{References}

$>1$ Elias J, Lee C, Zheng T, Ma B, Homer R, Zhu $\mathrm{Z}$ : New insights into the pathogenesis of asthma. J Clin Invest 2003;111:291-297.

$>2$ Panettieri R Jr: Airway smooth muscle: immunomodulatory cells that modulate airway remodeling? Respir Physiol Neurobiol 2003; 137:277-293.

$>3$ Brightling C, Bradding P, Symon F, Holgate S, Wardlaw A, Pavord I: Mast-cell infiltration of airway smooth muscle in asthma. N Engl J Med 2002;346:1699-1705.

4 Page S, Ammit A, Black J, Armour C: Human mast cell and airway smooth muscle cell interactions: implications for asthma. Am J Physiol 2001;281:L1313-L1323.

5 Pease J, Williams T: Chemokines and their receptors in allergic disease. J Allergy Clin Immunol 2006;118:305-318.

6 Ochi H, Hirani W, Yuan Q, Friend D, Austen $\mathrm{K}$, Boyce J: T helper cell type 2 cytokine-mediated comitogenic responses and CCR3 expression during differentiation of human mast cells in vitro. J Exp Med 1999;190:267280 .

7 Juremalm M, Olsson N, Nilsson G: Selective CCL5/RANTES-induced mast cell migration through interactions with chemokine receptors CCR1 and CCR4. Biochem Biophys Res Commun 2002;297:480-485.

$>8$ Brightling C, Ammit A, Kaur D, Black J, Wardlaw A, Hughes J, Bradding P: The CXCL10/CXCR3 axis mediates human lung mast cell migration to asthmatic airway smooth muscle. Am J Respir Crit Care Med 2005;171:1103-1108.
9 Matsukura S, Kokubu F, Kurokawa M, Kawaguchi M, Ieki K, Kuga H, Odaka M, Suzuki S, Watanabe S, Takeuchi H, Kasama T, Adachi M: Synthetic double-stranded RNA induces multiple genes related to inflammation through Toll-like receptor 3 depending on NF-kB and/or IRF-3 in airway epithelial cells. Clin Exp Allergy 2006;36:1049-1062.

10 Ieki K, Matsukura S, Kokubu F, Kimura T, Kuga H, Kawaguchi M, Odaka M, Suzuki S, Watanabe S, Takeuchi H, Schleimer R, Adachi M: Double-stranded RNA activates RANTES gene transcription through co-operation of nuclear factor-kappaB and interferon regulatory factors in human airway epithelial cells. Clin Exp Allergy 2004;34: 745-752.

11 Matsukura S, Stellato C, Plitt J, Bickel C, Miura K, Georas S, Casolaro V, Schleimer R: Activation of eotaxin gene transcription by NF-kappa B and STAT6 in human airway epithelial cells. J Immunol 1999;163:68766883.

12 Ghaffar O, Hamid Q, Renzi P, Allakhverdi Z, Molet S, Hogg J, Shore S, Luster A, Lamkhioued B: Constitutive and cytokine-stimulated expression of eotaxin by human airway smooth muscle cells. Am J Respir Crit Care Med 1999;159:1933-1942.

13 Moore P, Church T, Chism D, Panettieri R Jr, Shore S: IL-13 and IL-4 cause eotaxin release in human airway smooth muscle cells: a role for ERK. Am J Physiol Lung Cell Mol Physiol 2002;282:L847-L853.

14 Hirst S, Hallsworth M, Peng Q, Lee T: Selective induction of eotaxin release by interleukin-13 or interleukin-4 in human airway smooth muscle cells is synergistic with interleukin-1beta and is mediated by the interleukin-4 receptor alpha-chain. Am J Respir Crit Care Med 2002;165:1161-1171.
-15 Faffe D, Flynt L, Mellema M, Moore P, Silverman E, Subramaniam V, Jones M, Mizgerd J, Whitehead T, Imrich A, Panettieri RA Jr, Shore S: Oncostatin M causes eotaxin-1 release from airway smooth muscle: synergy with IL-4 and IL-13. J Allergy Clin Immunol 2005;115:514-520.

16 Peng Q, Matsuda T, Hirst S: Signaling pathways regulating interleukin-13-stimulated chemokine release from airway smooth muscle. Am J Respir Crit Care Med 2004; 169:596-603.

17 Zuyderduyn S, Hiemstra P, Rabe K: TGFbeta differentially regulates $\mathrm{TH} 2$ cytokineinduced eotaxin and eotaxin-3 release by human airway smooth muscle cells. J Allergy Clin Immunol 2004;114:791-798.

18 Hardaker E, Bacon A, Carlson K, Roshak A, Foley J, Schmidt D, Buckley P, Comegys M, Panettieri R Jr, Sarau M, Belmonte K: Regulation of TNF-alpha-and IFN-gamma-induced CXCL10 expression: participation of the airway smooth muscle in the pulmonary inflammatory response in chronic obstructive pulmonary disease. FASEB J 2004;18: 191-193.

19 Ammit A, Lazaar A, Irani C, O’Neill G, Gordon N, Amrani Y, Penn R, Panettieri R Jr: Tumor necrosis factor-alpha-induced secretion of RANTES and interleukin- 6 from human airway smooth muscle cells: modulation by glucocorticoids and beta-agonists. Am J Respir Cell Mol Biol 2002;26:465474 . 